\title{
THE INTONATION OF CONDITIONAL AND INTERROGATIVE PROMISES IN JORDANIAN ARABIC
}

\author{
Khalid Alsmadi ${ }^{1}$ \\ English Language, Prince Sattam Bin Abdul-Aziz University. \\ (Email: smadi_khalid@yahoo.com) \\ Kamariah Yunus ${ }^{2}$ \\ Faculty of Languages and Communication, Universiti Sultan Zainal Abidin. \\ (Email: kamariah@unisza.edu.my) \\ Yasmeen Almadani ${ }^{3}$ \\ Faculty of Languages and Communication, Universiti Sultan Zainal Abidin \\ (Email: E.1_2@live.com)
}

Received date: 12-11-2019

Revised date: 25-11-2019

Accepted date: 02-11-2019

Published date: 15-12-2019

To cite this document: Alsmadi, K ., Yunus, K., \& Almadani, Y. (2019). The Intonation of Conditional and Interrogative Promises in Jordanian Arabic. International Journal of Humanities, Philosophy and Language, 2(8), 217-230.

DOI: $10.35631 / \mathrm{ijhpl} .280016$

\begin{abstract}
This study aimed at investigating the intonation of interrogative and conditional utterances used to perform a promising speech act in Jordanian Arabic through analysing the utterances involved acoustically. Actually, it attempted to figure out the interrogative and conditional constructions carried out in the performance of a promising speech act along with the accompanying intonational patterns. The study data were composed of a definite number of recorded utterances by five Jordanian Arabic native speakers. The data were analyzed using "PRAAT software" (version No. 5304). Focusing on the measurements of the FO (pitch), the results indicated that a promising speech act would be performed using the first conditional, second conditional (fals promise), formal wh-question and informal wh-question used along with tones such as the high-fall, low-fall, and rise-fall tunes.
\end{abstract}

Keywords: Intonation, Interrogative, Conditional, Acoustic Analysis

\section{Introduction}

Intonation was defined by Bradford (1988: 1) as "a feature of the spoken language which involves a continuous pitch changing and a variation of a speaker's voice to express meaning". Intonation, in intonational languages like English and Arabic, does not denote lexical meaning, but rather, it delivers additional meanings, which would only be concluded from the intonational patterns. In Jordanian Arabic, for example, the word Rahlaw sahla (English: welcome) can be delivered (said) with different tunes to indicate various meanings. If such an expression is said with a falling tune, it might indicate a warm greeting. On the other hand, if it 
is said with a rising tune, it might be a sign of a cold greeting (Jaradat, 2009). Thus, the intonation plays a significant role in language and language communication. Overall, it represents extra ways by means of which we are able to convey both our emotions and state of mind. Furthermore, to lay down the paramount significance of intonation, imagine a language without intonation. Could its speakers communicate their feelings and emotions properly? Such a language will look like a robot's communication system, which lacks any sort of real human emotions and feelings. Consequently, intonation and other supra-segmental features are important things by which human beings are capable of communicating well.

Moreover, intonation is by and large regarded as a system which plays a vital part in contextualizing utterances in their conversational context (Selting, 2010). Unlike grammarians who divide a text into certain linguistic sections including sentences, phrases and words, phonologists, in terms of the intonation analysis, divide a text into intonational groups or units (Katamba, 1989). Cruttenden (1986) introduces some basic criteria that would help us determine the intonational group. He considers a pause, anacrusis (more known as unstressed syllables) and final syllable lengthening as marks which show the boundaries of the intonational group concerned. It is supposed that every intonational group has a systematic internal structure. According to many phonologists (Couper-Kuhlen, 1986; Katamba, 1989; Rouch, 2009), the intonational group is largely envisaged to have these components: Pre-head, head, tonic syllable and tail. See the following example from Katamba (1989).

$\begin{array}{llll}\text { (Pre- head) } & \text { (Head) } & \text { Nucleus or tonic } & \text { (Tail) } \\ \text { He will } & \text { phone you when } & \text { all }\end{array}$

\section{Statement of the Problem}

Following the assumption that a lot of communication barriers, remarkable misconceptions and unsuccessful interacts might stem from misused intonational patterns which are especially produced by foreign learners of a language, an immediately needed study is required to be conducted in this field. Rozaimie (2014) argues that voice and pitch contours (tone) play an important role in the effectiveness of interpersonal relationships and communication. He suggests that one of the several speaking skills required to effective interpersonal communication is stressing appropriate rhythmic patterns to avoid misinterpretations and misuse of intonation which lead to various unintended meanings such as arrogance, annoyance and insulting. Moreover, the related literature review claims that there is no study addressing the conditional and questions utterance within the scope of the promising speech act in standard Arabic or any Arabic dialect. Given that many linguists have not addressed the promising speech act in terms of the acoustic nature of conditional and questions, it is supposed that there is a need to conduct a study on Arabic intonation of promising.

\section{Purpose of the Study}

This study aims at identifying the conditionals and interrogative promises in Jordanian Arabic as well as figuring out the intonation patterns used in performing such a speech act.

\section{Research Questions}

The study strives to answer the following questions:

1. What are the possible conditional and interrogative utterances used to perform warning speech act?

2. What are the possible pitch contours assigned to these sentence types? 


\section{Limitations of the Study}

The study is confined to investigate the conditional and interrogative utterances used to perform promising speech act in the Jordanian Arabic dialect used in the northern area of Jordan. To do so, acoustic analysis is carried out for the target utterances that are recorded by 5 male native speakers of Jordanian Arabic whose age range from 22 to 30 years old. Thus, the analysis accounts only for fundamental frequency parameter (pitch) and for that period of age. However, since promising speech act can be performed using paralinguistic strategies such as body language in addition to the linguistic strategies that comprise single words, phrases and utterances, the present study examines the utterances only.

\section{Related Literature}

Lanius (2019) put promising speech act within the category of contracts where he assumes that contracts involve two independent speech act performed by two persons, whereas, the first person makes an offer, the other one accepts it. Thus, offer, and acceptance in this sense mean promising or commissive acts in general. Hickey (1986) designates the speech act of promising as a commitment speech act. He assumes that such a commitment is fundamental of binding and moral nature; it binds a person to take his moral responsibility and fulfil the action to which he has committed himself.

Beller, Bender \& Kuhnmunch (2005) investigate the commonalities and differences between promising and threatening speech acts using conditional phrases. Accordingly, they define speech acts of conditional promises as those acts which are exploited to affect other people's attitude or behaviour. They assume that conditional promises would be approached from various levels such as the motivational level which might, as a consequence, bring other related levels such as the linguistic, deontic (obligation), behavioural and emotional levels. In sum, a promising speech act is heavily used to persuade others with our plans, control others' behaviour or encourage and reinforce the hearer to do something at our disposal.

Al-Salim (2010) carries out an acoustic analysis of threatening intonation of Jordanian Arabic and American English. Analysing acoustically the recorded dialogues, which contain the threatening speech act in both Jordanian Arabic and American English, he deduces that both languages use seven strategies to perform the threatening speech act. These strategies are the following: if- clause type one, imperative order, imperative command, imperative prohibition, declarative verb clause, interrogative yes/no question and if-clause type two. He also concludes that although both languages adopt the same strategies, they use different intonational patterns in performing threatening speech act. For example, 75\% of Arabic speaking subjects use a risefall tune with if clause type one, meanwhile $75 \%$ of American speaking subjects use a rise- fallrise tune with if clause type one.

Benghadeer (2008: 1-19) investigates Saudi EFL learners' pitch range and compares it with that of the native speakers. Analyzing 52 female students' utterances through pitch tracks and spectrograms, she concludes that non-speakers have narrower pitch range than native speakers. Furthermore, she states that the differences between the mean pitch range used by non-native and native speakers are only remarkable for the utterances produced with a falling contour as opposed to the ones produced with a rising one.

\section{Properties of Promising Speech Act}

Promising speech act would be characterized as a commitment contract between the speaker and the hearer in which the speaker puts voluntarily himself under a certain obligation to do a 
definite act in the future. Austin (1962) claims that commissives express the case whereby the speaker is committed to a certain act. In addition, Searle (1979) provides more elaboration on the nature and properties of promising. He determines a set of conditions that govern promising. Table 1 summarizes these conditions with some needed specification.

\section{Table 1: Searle (1979) Conditions of Promising Speech Act}

\begin{tabular}{|l|l|}
\hline 1- Preparatory condition & $\begin{array}{l}\text { The speaker is able to perform the action, } \\
\text { and the hearer wants the speaker to } \\
\text { perform the action. }\end{array}$ \\
\hline 2- Sincerity condition & The speaker intends to do the action \\
\hline 3- Propositional content condition & The speaker predicates a future action \\
\hline 4- Essential condition & $\begin{array}{l}\text { Counts as the undertaking by the speaker } \\
\text { of an obligation to do the action }\end{array}$ \\
\hline
\end{tabular}

Based on Searle's conditions and Austin's classification, it is reasonable to conclude that there are three properties of promising speech act: intention which is related to sincerity condition, future time synchronicity which is connected with the propositional content condition and the obligation which is linked to the essential condition. Hence, along with the obligation, the speaker's intention to do the action as well as the future time on which the action is supposed to take place can be regarded as additional characteristics of a successful promise.

\section{Methodology}

\section{Research Design}

The study is based on the exploratory research design where it seeks to discover the conditional and interrogative utterances which perform promising speech act in Jordanian Arabic as well as the intonational patterns that accompany them.

\section{The population of the Study}

The study population consists of 5 male native speakers of Colloquial Jordanian Arabic in Irbid (located in the north of Jordan). This dialect is mainly used in the rural areas of Irbid governorate such as Bait Yafa, Taiba, etc.

\section{Sample of the Study}

Along with the control person who is 30 years old and an MA student of linguistics, the sample consists of five male native speakers of the rural area dialect of Ibid; with ages ranging from 22 to 30 years old. It goes without saying that all the subjects were born and raised in Irbid, without any speech defects or speech-related biological obstacles.

\section{Data Collection and Mechanism}

The main mechanism used to collect the data needed is recording dialogues, which do actually contain utterances performing promising speech act in Jordanian Arabic in a quiet room. To attain such a goal, the role of the control has been adopted to elicit the common intonational patterns and guide the participants throughout the recording process.

\section{Data Analysis}

The recorded dialogues have been segmented and analysed by using PRAAT software (6104). Such technology enables us to record, analyze and manipulate the speech. In addition to creating high-quality spectrogram pictures for articles and theses, such a program also makes it possible 
for us to analyse the pitch contours, formants frequencies, intensity and duration. It is worth pointing out that the pitch range is to be modified from $75-500 \mathrm{~Hz}$, which is the default standard for PRAAT, to $60-500 \mathrm{~Hz}$ so that lower pitch occurrences could be captured. Further, the current analysis focuses on the fundamental frequency, which measures whether the frequency of a person's voice sounds is high or low. It is correlated with pitch and can be abbreviated to (F0). As for the intonational model of analysis, the present study follows the British style of intonational analysis which is called configuration pitch levels. This model (proposed by Halliday, 1967a; crystal, 1969; O'Connor and Arnold, 1973) describes intonation based on nuclear tone approach in which the greatest change on pitch (fall or rise) usually occurs on the most prominent syllable in the intonational group. (as cited in Grice \& Baumann, 2007).

\section{Findings}

This section provides an acoustic analysis of the target promising utterances used in Jordanian Arabic. More specifically, it discusses the findings, which are related to pitch contours of promising utterances.

\section{Pitch Analysis}

This analysis is intended to give clear indications about the important words, the last important words and the stressed syllables which reflect the pitch change in the whole word groups. To achieve this goal, the analysis makes use of two waveforms in each utterance analysis. The first one represents the utterance pitch contour, and the second reflects the pitch contour of the stressed syllable.

\section{First Conditional}

The first conditional utterance /wuṭlub ili baddak iyyaah/ (Ask whatever you want) contains three important words: /wuṭlub/, /baddak/ and /iyyaah/. Furthermore, analysing this utterance shows that the word /iyyaah/ is the last important word since it comprises the stressed syllable liy/, reflecting the pitch change in the whole word group. However, the choice of the stressed syllable is not fixed for all the subjects in this utterance. Analysing the oscillation of pitch for subject D's utterance, the researcher finds out that subject D chooses the word /wutlub/ as the last important word and the syllable /wut/ as the stressed syllable of the last important word to express the pitch change in the whole word group. Such a change is illustrated in waveform 1 for the control and the five subjects.

Waveform 1: Pitch Contours of /Wuṭlub ili baddak iyyaah/

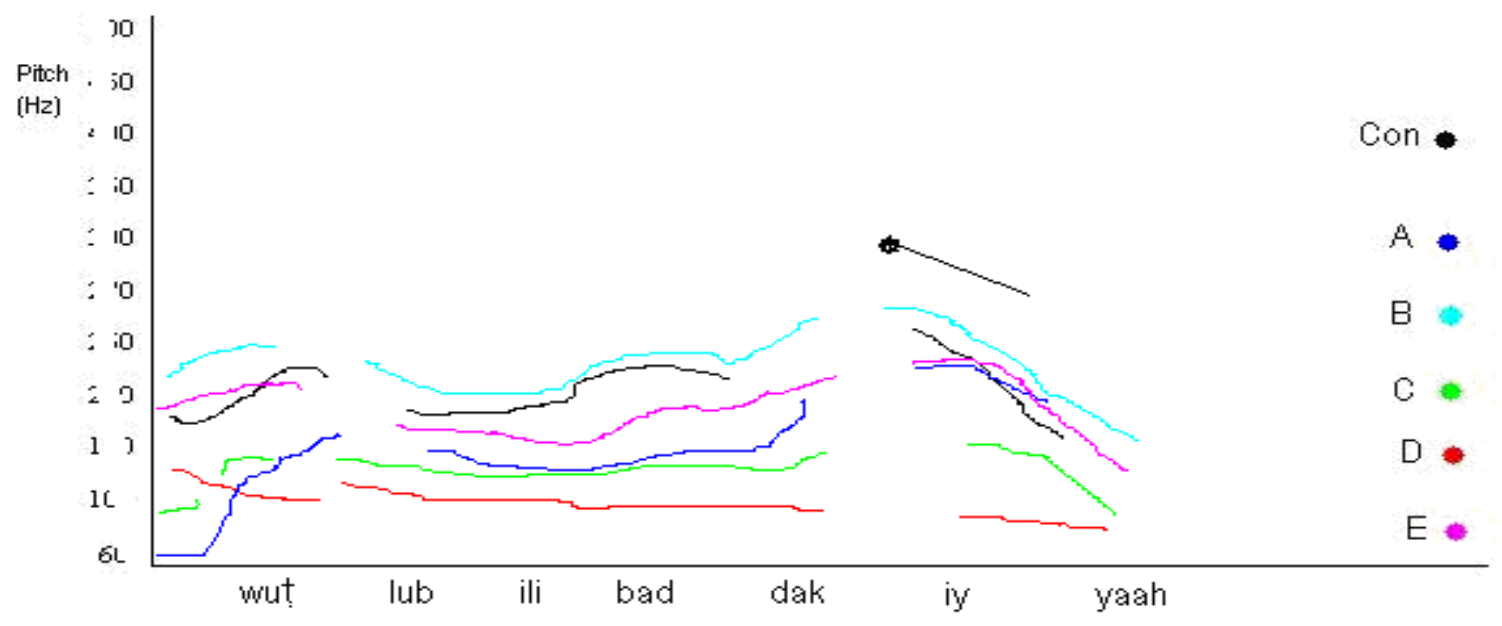


As illustrated in wave form 1 the control's pitch contour for the utterance /wutlub ili baddak iyyaah/ begins with $173.44 \mathrm{~Hz}$ and rises to $254.07 \mathrm{~Hz}$ on the head constituent of the word group before falling to $210.31 \mathrm{~Hz}$ on the stressed syllable of the last important word. During the stressed syllable /iy/, the peak /i/ commences with a pitch that is about $210.31 \mathrm{~Hz}$, it then starts lowering to $171.47 \mathrm{~Hz}$ at the middle of the peak and $130.41 \mathrm{~Hz}$ at the end of the peak. Consequently, the control produces his utterance with a high-fall tune. Moreover, the waveform demonstrates that the five subjects also produce the utterance with a falling tune. However, investigating the measures of pitch might add some features to this falling tune. Since the control, subject $A$, subject $B$ and subject $E$ have higher pitch height than subject $C$ and subject $\mathrm{D}$, it can be concluded that the control, subject A, subject $\mathrm{B}$ and subject E produce the utterance with a high-fall tune, whereas subjects $\mathrm{C}$ and $\mathrm{D}$ produce it with a low-fall tune. Waveform 2 indicates the high-fall and low-fall tunes of the stressed syllables /iy/ and /wut/ for both the control and the five subjects.

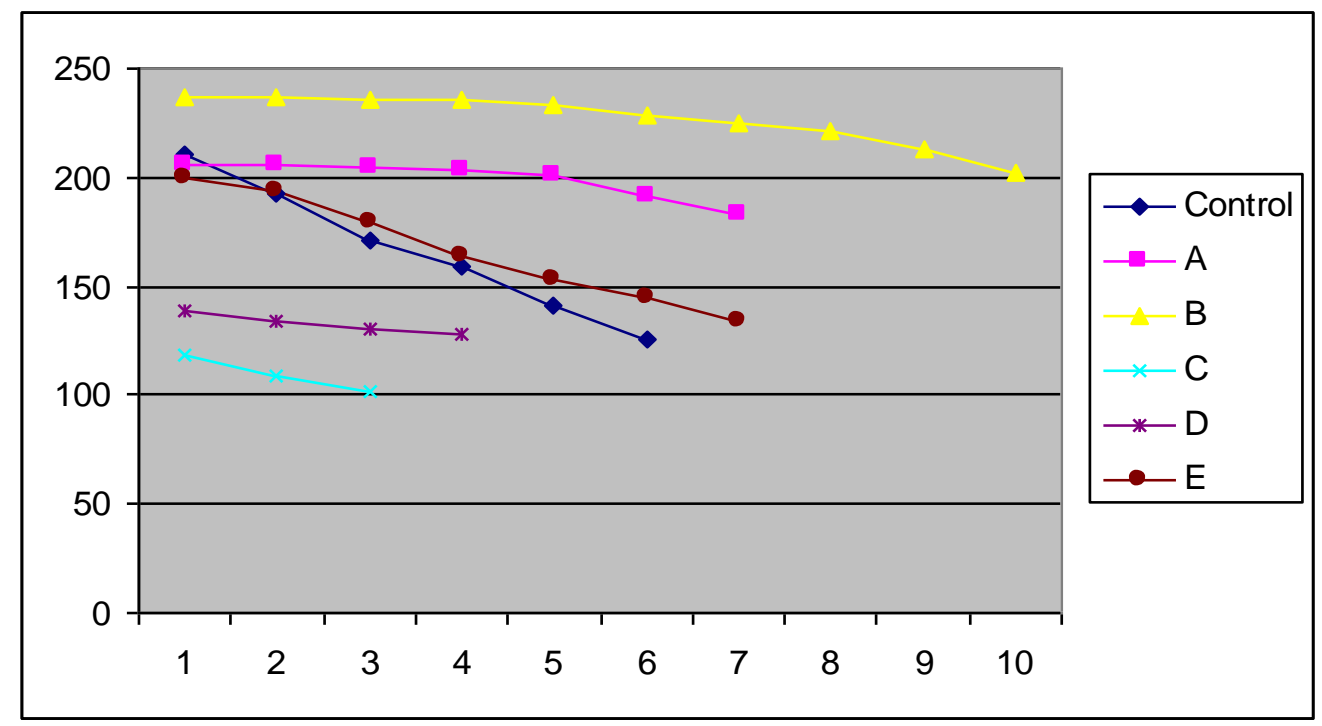

\section{Waveform 2: Pitch Contours of the Stressed Syllables /iy/ and /wut/ for the Control and the Five Subjects}

\section{Second Conditional}

Dialogue $3^{1}$ shows that the second conditional utterance /taay nawwir ilmileh xayyooh/ (I pledge not to let you have what you want) performs a negative promise whereby the promisor has an intention to do the opposite of what the promisee asks. The utterance has two important words: /taaynawwir/ and /ilmileh/. The word /ilmileh/ is the last important word due to the fact that it includes the stressed syllable /leh/ which exhibits the pitch change in the whole word group. Such a change in pitch for the control and the five subjects can be seen in waveform 3 below.

\footnotetext{
${ }^{1}$ See the appendix where the full dialogues of the study are available
} 


\section{Waveform 3: Pitch Contours of /taay nawwir ilmileh xayyooh/}

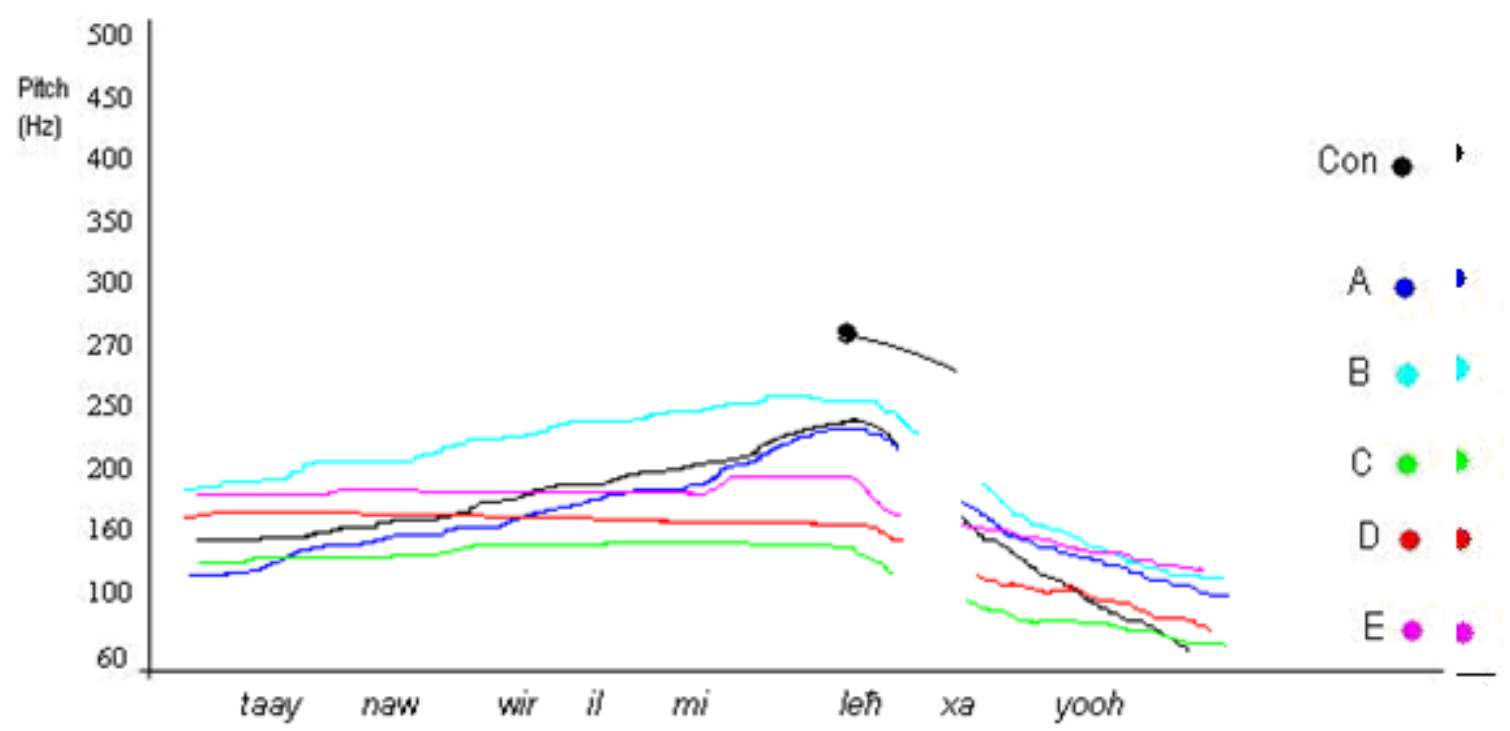

The waveform 3 for the utterance /taay nawwir ilmileh xayyooh/ indicates that the control's pitch contour commences with 157.47 and ascends to $240.87 \mathrm{~Hz}$ on the head constituent of the word group, then it falls to $214.58 \mathrm{~Hz}$ on the stressed syllable /leh/ of the last important word. After that, the falling movement persists its course on the tale constituent of the word group represented by the word /xayyooh/ and reaches $67.11 \mathrm{~Hz}$ at the end of the whole utterance. Concerning the stressed syllable, the onset starts with $214.58 \mathrm{~Hz}$ and keeps falling until it records $185.59 \mathrm{~Hz}$ at the end of the peak /e/. The coda of the stressed syllable / $\mathrm{h} /$ has no pitch representation since it is a voiceless sound during which vocal cords do not vibrate. So, the pitch analysis of the stressed syllable states that the control has a high-fall tune for this utterance. Moreover, analysing the five subjects' pitch contours shows that they all agree with the control in producing the utterance with a falling tune. Nevertheless, it can be seen in Waveform 6 below that subject C, and D produce their stressed syllables with a lower pitch height than the control and the other subjects. Subsequently, it is obvious that subject A, subject $\mathrm{B}$ and subject $\mathrm{E}$ agree with the control in pronouncing the utterance with a high-fall tune, while subject $\mathrm{C}$ and subject $\mathrm{D}$ produce it with a low-fall tune. The waveform 4 below reflects the high-fall and the low-fall pitch contours of the stressed syllable /leh/ for the control and the five subjects. 


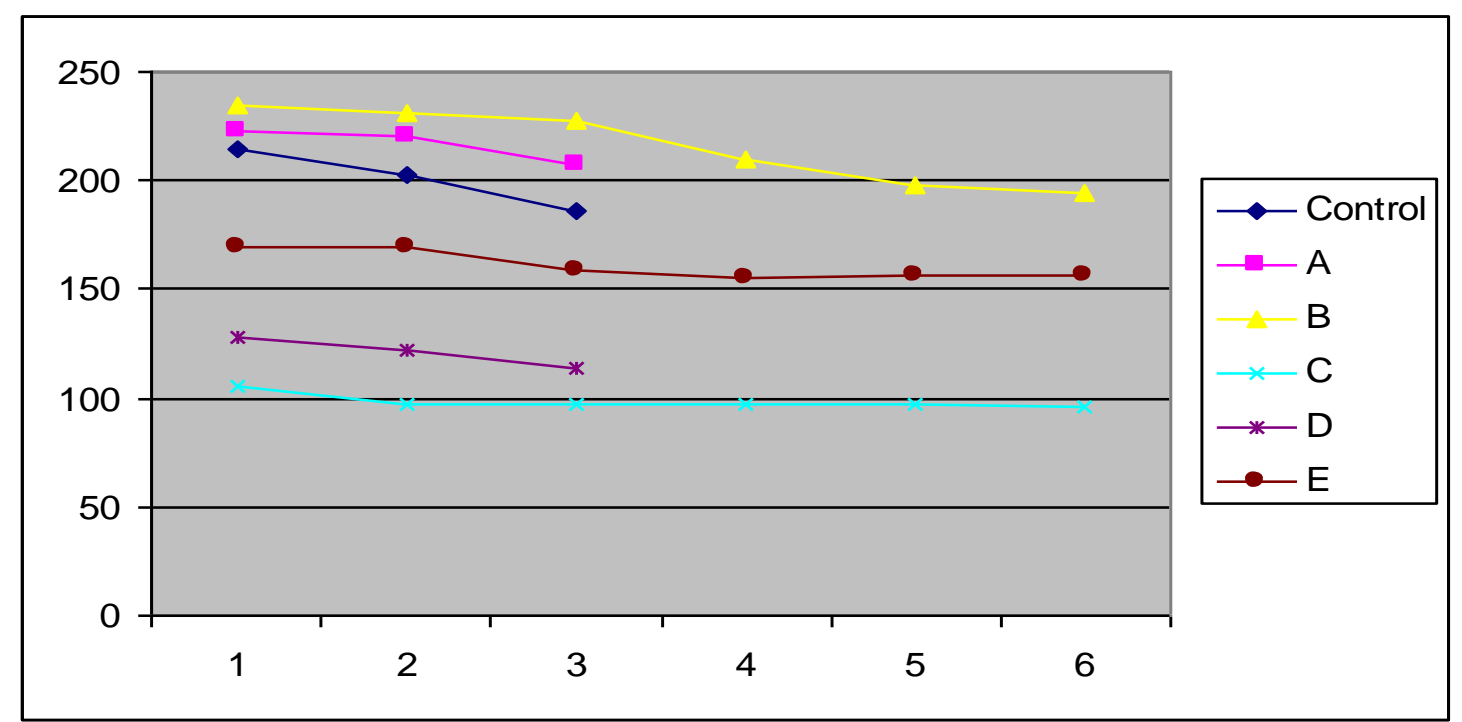

Waveform 4: Pitch Contours of the Stressed Syllable /leh/ for the Control and the Five Subjects

\section{Formal Wh-Question}

Examining dialogue 3 reveals that the utterance /Puleeš ma?adziibha/ (Why do not I have such a thing?) which performs promising speech act has two important words: /?uleeš/ and /ma?adziibha/. Moreover, it is evident that the word / Puleeš/ is the last important word since it holds the stressed syllable /leeš/, reflecting the pitch change in the whole word group. The waveform 5 clarifies this change for the control and the five subjects.

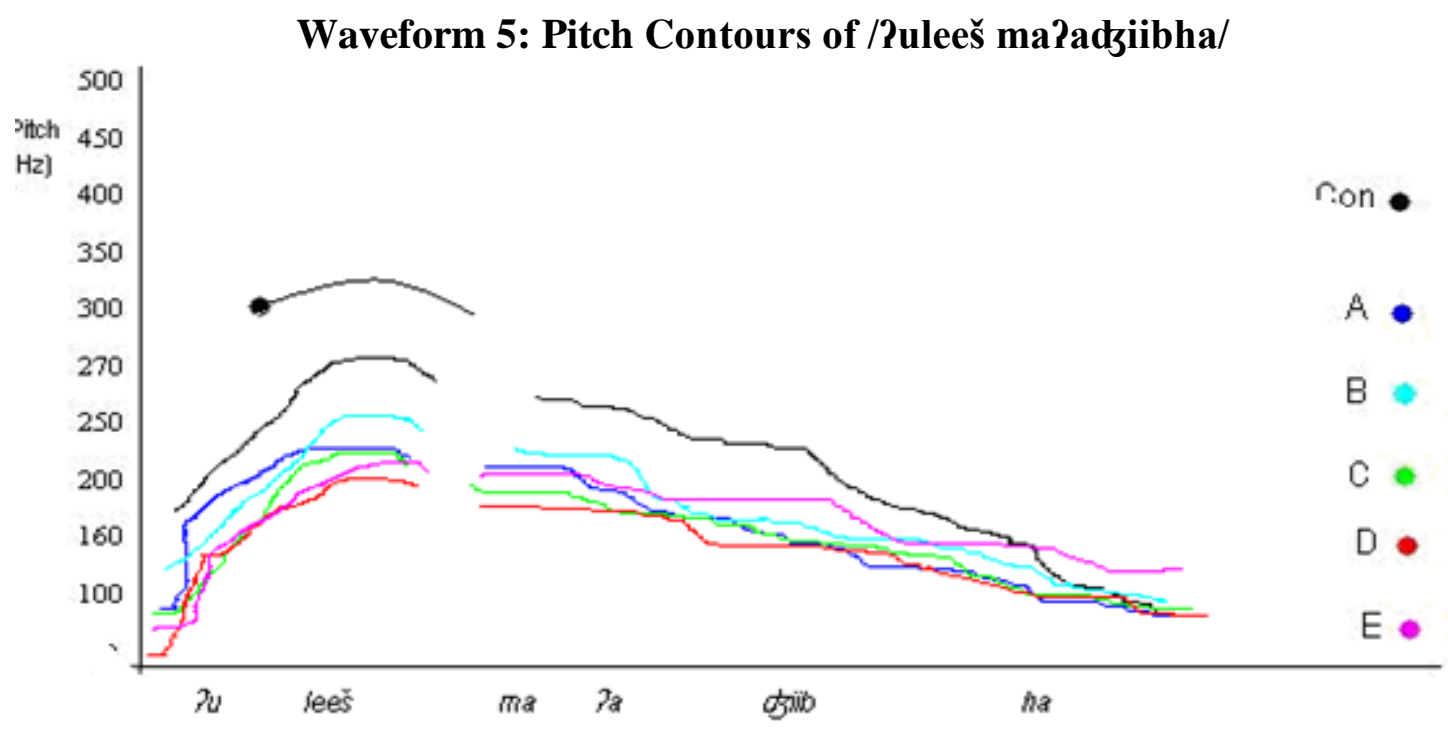

As shown in waveform 5 for the formal wh-question utterance / Puleeš maPadziibha/, the control's pitch contour starts with $180.23 \mathrm{~Hz}$ and rises to $278.56 \mathrm{~Hz}$ on the stressed syllable /leeš/, then it starts falling to $253.03 \mathrm{~Hz}$ on the same syllable until it reaches $86.05 \mathrm{~Hz}$ at the end of the utterance. Within the stressed syllable, the pitch of the onset /l/ is about $259.66 \mathrm{~Hz}$. It, then, goes up and reaches its maximum rise which amounts to $278.50 \mathrm{~Hz}$ at the middle of the peak /ee/. Soon after that, the pitch contour of the stressed syllable begins to decline to $249.38 \mathrm{~Hz}$ at the end of the peak. The coda / $\breve{s} /$ has undefined pitch since it does not involve 
vocal folds vibration. As a result, the control produces this promising utterance with a rise-fall tune. Regarding the five subjects, the waveform shows that all of them agree with the control in pronouncing this utterance with similar pitch configurations. The waveform 6 reflects the rise-fall pitch contours of the stressed syllable for the control and the five subjects.

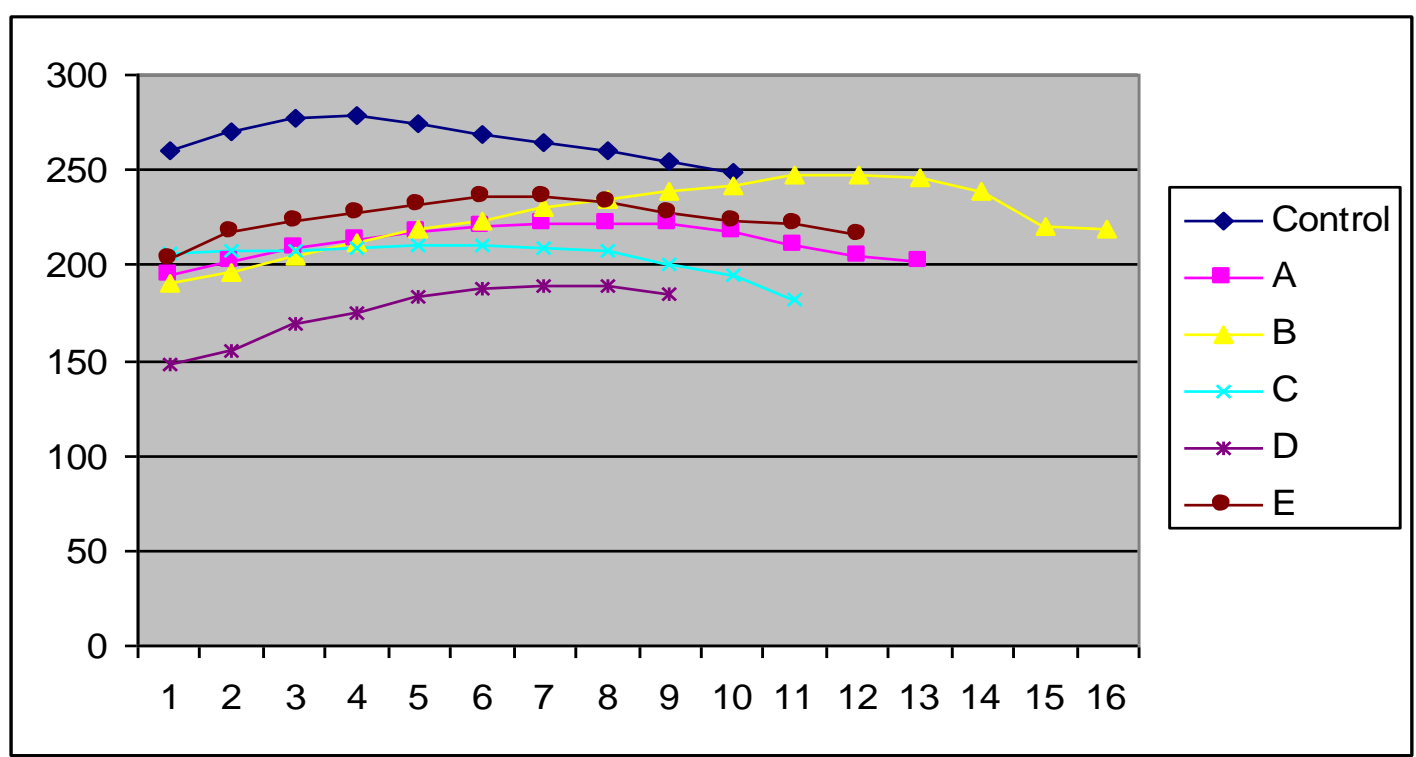

Waveform 6: Pitch Contours of the Stressed Syllable /leeš/ for the Control and the Five Subject

\section{Informal Wh- Question}

In addition to the fact that it is used as a phatic expression in dialogue 4, the informal whquestion utterance /miin bigdar Pigullak la?/ (who dares to say no to you?) performs promising speech act. The utterance has two important words: /miin/ and /bigdar/. As a matter of fact, the word /bigdar/ is the last important word because of having the stressed syllable /big/, governing the pitch change in the whole word group. The waveform 7 reflects this change for both the control and the five subjects.

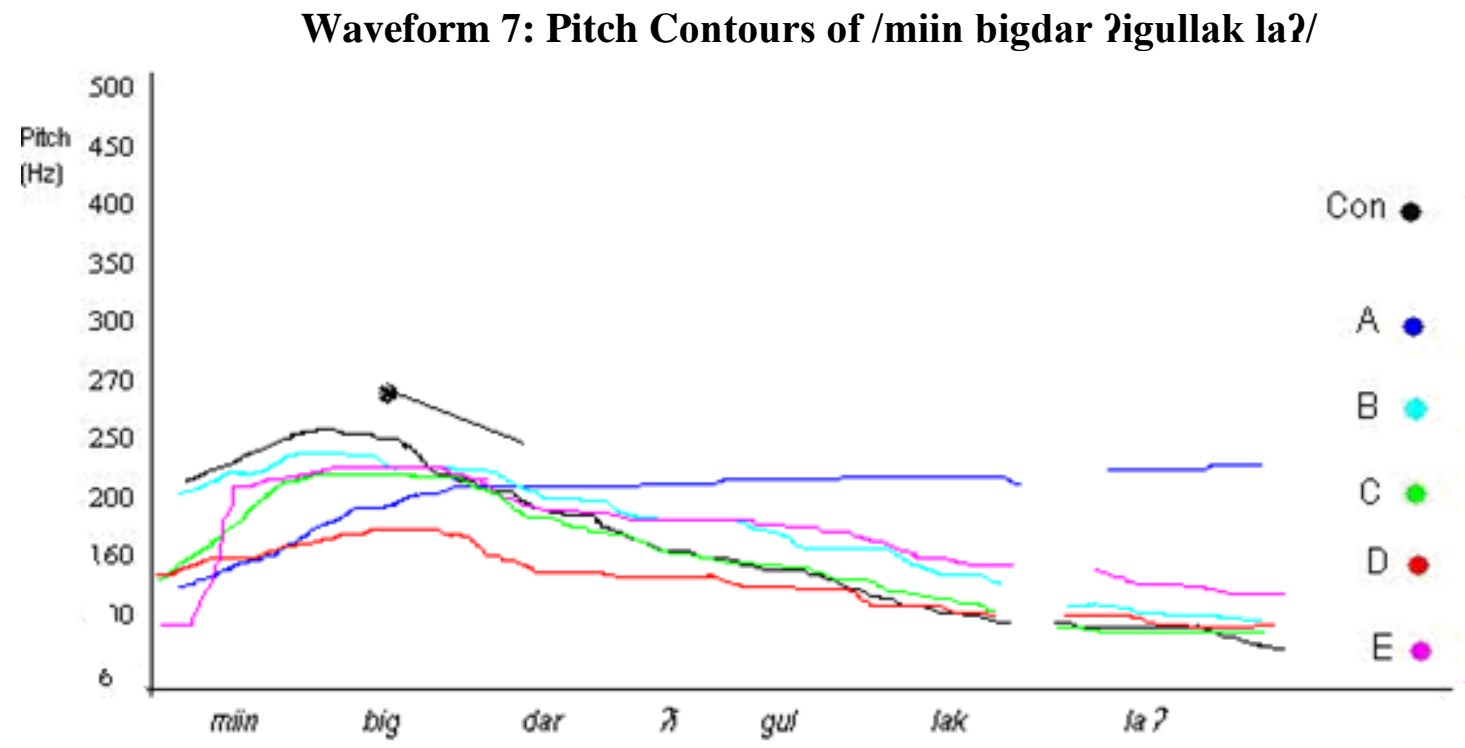


The control's pitch contour for this utterance which is represented in waveform 7 starts with $208.69 \mathrm{~Hz}$ and rises to $264.00 \mathrm{~Hz}$ on the head constituent of the word group /miin/ before it changes its direction of movement and starts falling to $192.56 \mathrm{~Hz}$ on the stressed syllable /big/ of the last important word. The falling movement, then, continues during the tale constituent till it reaches $92.30 \mathrm{~Hz}$ at the end of the whole utterance. For the stressed syllable, the onset /b/ begins with 192.56, goes down to $159.69 \mathrm{~Hz}$ at the middle of the peak and continues its falling movement until it has a record which amounts to $133.07 \mathrm{~Hz}$ at the coda $/ \mathrm{g} /$. Consequently, the pitch measures of the whole utterance and the stressed syllable indicate that the control produces this utterance with a high-fall tune to perform promising. For the five subjects, they tend to follow the control in his production except for subject A and subject D. The waveform 9 shows that although subject D produces the promising utterance with a falling tune, he has a lower pitch height than the control and the others. The pitch analysis of the stressed syllable indicates that the onset /b/ starts with $146.87 \mathrm{~Hz}$ and directly falls to $135.16 \mathrm{~Hz}$ at the coda of that syllable. Thus, subject D's stressed syllable falling pitch contour starts from $146.87 \mathrm{~Hz}$; whereas the control and the other subjects stressed syllables' falling pitch contours start from a point that is higher than $179.34 \mathrm{~Hz}$. Consequently, this subject produces the utterance with a low-fall tune. The pitch contour of subject A begins with 128.27 and starts rising to $190.48 \mathrm{~Hz}$ on the stressed syllable of the last important word. Then, the rising movement keeps its course through the tale constituent till it reaches $209.04 \mathrm{~Hz}$ at the end of the whole utterance. Within the stressed syllable, the pitch of the onset /b/ begins with $185.84 \mathrm{~Hz}$ and starts rising to $190.48 \mathrm{~Hz}$ at the middle of the peak /i/ until it reaches $196.00 \mathrm{~Hz}$ at the coda /g/. Accordingly, the pitch measures of this subject indicate that he uses a rising tune in producing this utterance.

The main difference between this subject and the others is related to the pitch movement which occurs specifically on the stressed of the last important word. Unlike the control and the others who have stressed syllables which express falling tune, subject A's stressed syllable reflects a rising tune. Based on the previous analysis, it is obvious that the control, subject B, subject $\mathrm{C}$ and subject $\mathrm{E}$ produce the utterance with a high-fall tune as opposed to subject $\mathrm{D}$ and subject A who produce it with a low-fall tune and rising tune, respectively. The waveform 8 illustrates the high-fall, low-fall and the rising tunes of the stressed syllable /big/ for the control and the five subjects.

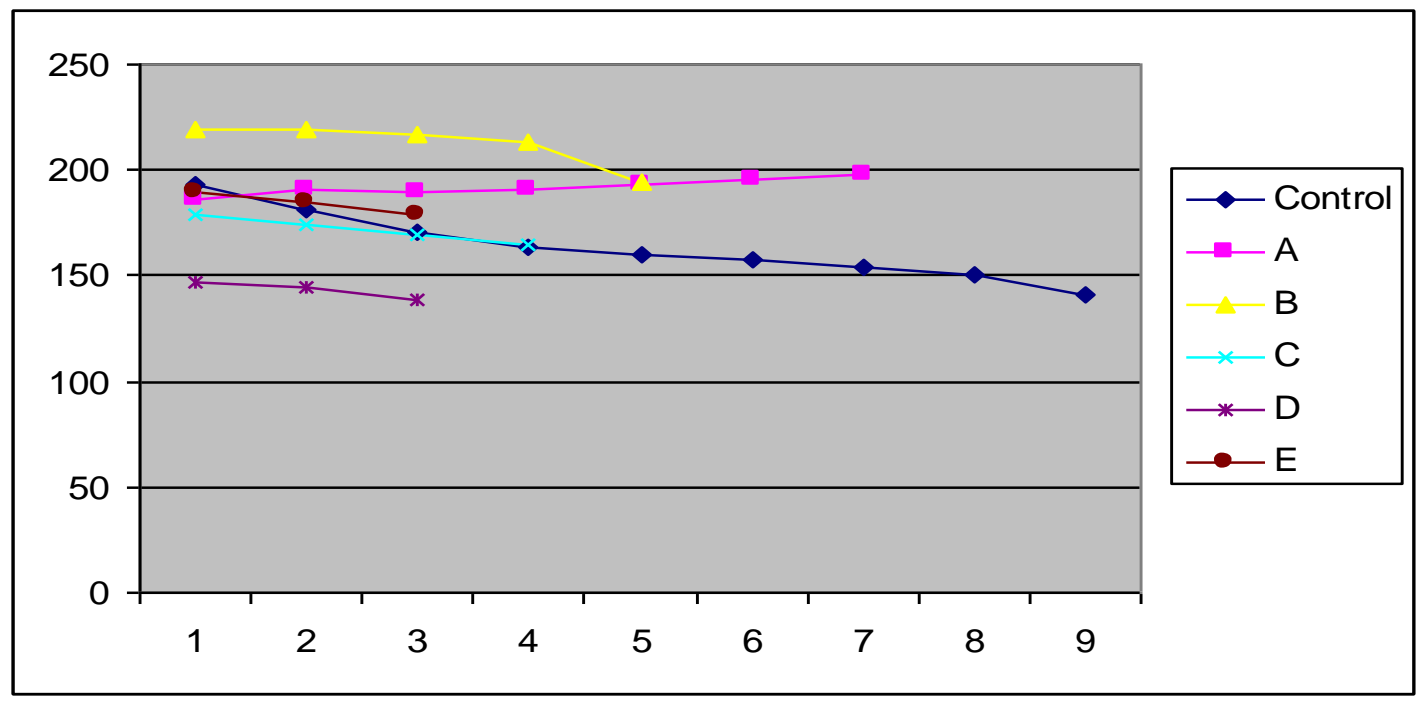

Waveform 8: Pitch Contours of the Stressed Syllable /big/ for the Control and the Five Subjects 


\section{Conclusion}

The study has answered its questions and concluded the following major issues:

The findings show that the promising speech act would be performed through using first conditional, second conditional (false promise), formal wh-question and informal wh-question. Moreover, the given results maintain the following percentages of the subjects' ability to match the control production.

- $60 \%$ of the subjects agree with the control's production of the first conditional structure with a high-fall tune, whereas $40 \%$ produce it with a low-fall tune.

- $60 \%$ of the subjects go along with the control in producing the second conditional (false promise) with a high-fall tune, whereas $40 \%$ produce it with a low-fall.

- $100 \%$ of the subjects match the control's production of the formal wh-question with a rise-fall tune.

- $60 \%$ of the subjects agree with the control in producing the informal wh-question structure with a high-fall; meanwhile, $20 \%$ produce it with a low-fall and $20 \%$ with a rising tune. Table 2 below summarises the pitch contours used in Jordanian Arabic to perform promising.

Table 2: The Promising Utterances Pitch Contours with Relevance to their Sentence Type

\begin{tabular}{|c|c|c|c|c|c|}
\hline Structure & Subject & Pitch Contours & Structure & Subjects & $\begin{array}{l}\text { Pitch } \\
\text { Contours }\end{array}$ \\
\hline \multirow{6}{*}{$\begin{array}{l}\text { First } \\
\text { Conditional }\end{array}$} & Control & High-fall & \multirow{6}{*}{$\begin{array}{l}\text { Second } \\
\text { Conditional } \\
\text { (false } \\
\text { promise) }\end{array}$} & Control & High-fall \\
\hline & $\mathrm{A}$ & High-fall & & $\mathrm{A}$ & High-fall \\
\hline & $\mathrm{B}$ & High-fall & & $\mathrm{B}$ & High-fall \\
\hline & $\mathrm{C}$ & Low-fall & & $\mathrm{C}$ & Low-fall \\
\hline & $\mathrm{D}$ & Low-fall & & $\mathrm{D}$ & Low-fall \\
\hline & $E$ & High-fall & & $E$ & High-fall \\
\hline \multirow{6}{*}{$\begin{array}{l}\text { WH- } \\
\text { Question } \\
\text { (Formal) }\end{array}$} & Control & Rise-fall & \multirow{6}{*}{$\begin{array}{l}\text { WH- } \\
\text { Question } \\
\text { (Informal) }\end{array}$} & Control & High-fall \\
\hline & $\mathrm{A}$ & Rise-fall & & $\mathrm{A}$ & Rising \\
\hline & $\mathrm{B}$ & Rise-fall & & $\mathrm{B}$ & High-fall \\
\hline & $\mathrm{C}$ & Rise-fall & & $\mathrm{C}$ & High-fall \\
\hline & $\mathrm{D}$ & Rise-fall & & $\mathrm{D}$ & Low-fall \\
\hline & $E$ & Rise-fall & & $E$ & High-fall \\
\hline
\end{tabular}

Moreover, such findings indicate that the illocutionary force of promise is more connected with intonation rather than the sentence types. In other words, although promising speech act can be performed using several sentence types, these sentence types seem to be produced with a limited number of pitch contours. Hence, the study results reflect the fact that pitch contours can be used as a signifier for a promising speech act. In conclusion, the present study supports some of the facts related to the relationship between the illocutionary acts and intonation. Besides, it adds more to the relation between the illocutionary force of promise and the allocated pitch contours. 


\section{References}

Al-Salim, A. (2010). Acoustic Threatening Intonation in Jordanian Arabic and American English. Unpublished MA thesis, Yarmouk University, Irbid, Jordan.

Austin, J. L. (1962). How to Do Things with Words. USA: President and Fellows of Harvard College.

Beller, S., Bender, A., \& Kuhnmünch, G. (2005). Understanding conditional promises and threats. Thinking \& Reasoning, 11(3), 209-238.

Binghadeer, N. (2008). An acoustic analysis of pitch range in the production of native and nonnative speakers of English. The Asian EFL Journal Quarterly, 10, 96-113.

Bradford, B. (1988). Intonation in Context: Intonation practice for Upper-Intermediate and Advanced Learners of English. Cambridge: Cambridge University Press.

Couper- Kuhlen, Elizabeth. (1986). An Introduction to English Prosody. London: Edward Arnold Ltd.

Cruttenden, A. (1986). Intonation. Cambridge: Cambridge University Press.

Grice, M., \& Baumann, S. (2007). An introduction to intonation-functions and models. Nonnative prosody: Phonetic description and teaching practice. Berlin. Walter de Gruyter $\mathrm{GmbH} \& \mathrm{Co}$.

Hickey, R. (1986). A promise is a promise: On speech acts of commitment in English.

Jaradat, A. (2009). The Pragmatic Function of Intonation in Irbid Dialect. Unpublished MA thesis. Yarmouk University, Irbid, Jordan.

Katamba, Francis. (1989). An Introduction to Phonology. New York: Long man.

Lanius, D. (2019). Strategic Indeterminacy in the Law. Oxford Studies in Language and.

Rajimwale, S. (2006). Handbook of Linguistic Terms. India: Sarup\& Sons.

Roach, P. (2009). English Phonetics and Phonology. Fourth edition. Cambridge: Cambridge University Press.

Rozaimie, A. (2014). Communication \& Relationship. Singapore: Partridge.

Searle, John R. (1979). Expression and Meaning: Studies in the Theory of Speech Acts. Cambridge: Cambridge University Press.

Selting, M. (1987). Descriptive categories for the additive analysis of intonation in conversation. Journal of Pragmatics, 11(6), 777-791.

\section{Appendix}

This section presents the recorded dialogues of the study data, which have been acoustically analyzed in this study. These utterances are written bold and underlined as follows.

\section{Dialogue No (1): First Conditional Structure}

Pal Pab: /leeš yabah Salamaatak ibtixzi/

Pal Pibn: /mafih Ginddana im Salim Suluum Parđ Pu aylab lem Salmiin bimađuha idzazaat/

Pal 2ab: /bas Pani šufit Galamaat zumalaa?ak mašallah Galeeha yaSni iltagșiir min hađrit dzanaabak/

Pal Pibn: / Pani mabaguuliš inuh Pani miš imgașir bas bawGidak inni Pahassin Galamaati Galfașil ildzay/

Pal Pab: /yabah allah yirđa Saleek hassinli Salaamtak wutlub ili baddak iyyaah/

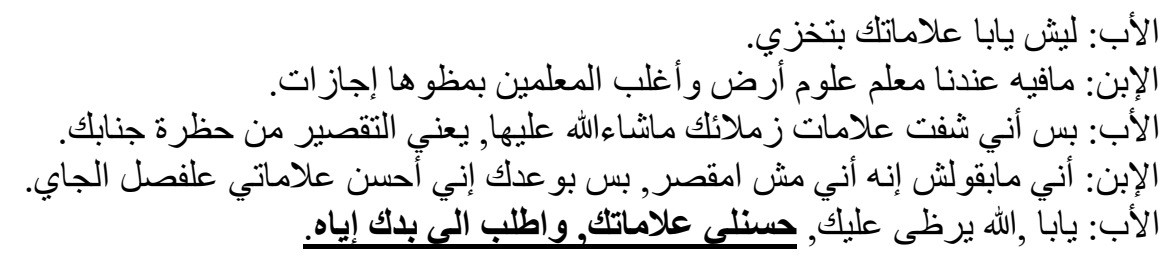


The father: My son, why do you have disappointing grades?

The son: There is no geomorphology teacher, and most of the teachers take a lot of vacations. The father: I have checked your colleagues' marks, and they have good grades. I can deduce that you are doing less than what is expected.

The son: I am not saying that I am a studious student, but I promise you that I will improve my grades in the next semester.

The father: May Allah be satisfied with you my son. Improve your grades at the next semester and ask whatever you want.

\section{Dialogue No (2): Second Conditional False Promise}

Pabu Muhammad: /ilyoom țihit Salbaladryh Galašan yiftaћulna haltariig/

Pabu ?üman: / Paywah wušuh șar maSak/

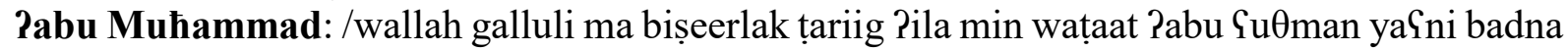
Pindzur Saleek ibmitreen $\theta$ alaa $\theta /$

Pabu ?üman: /taay nawwir ilmileh xayyooh/

$$
\begin{aligned}
& \text { أبو محمد: اليوم طحت عالبلديه عشان يفتحولنا هالطريق. }
\end{aligned}
$$

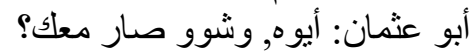

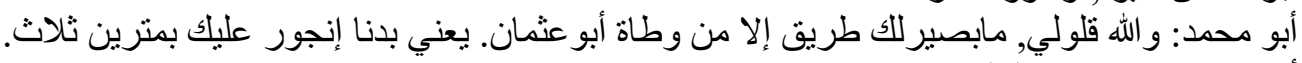

$$
\begin{aligned}
& \text { أبو عثمان: تاي ينور الملح خيوه. }
\end{aligned}
$$

Abu Mohammad: I went to the municipality, so that they could open the road.

Abu Othman: Ah, how did they respond?

Abu Mohammad: They said that there is no way else to do that unless you permit them to open the road from your own land.

Abu Othman: I pledge not to let you have what you want.

\section{Dialogue No (3): Formal WH-Question}

Pal šurți: /law samahit ruxașak/

Pal sa?iq: /itfađal/

Pal šurți: /maSak țafayeh Pu Sakiseh/

Pal sa?iq: /walla Sakiseh maSi bas ilțafayeh Sațlaneh/

Pal šurți: /kul siyarah lazem iykuun fiha țafayeh heek iltaSlimaat/

Pal sa?iq: / yaxooy wallah dafaCit xamssiin dinaar gabl išway taṣleeh lasiyaarah walla bas yinzel ilratib la?aštari țafayeh/

Pal šurți: / akiid bitdłiibha/

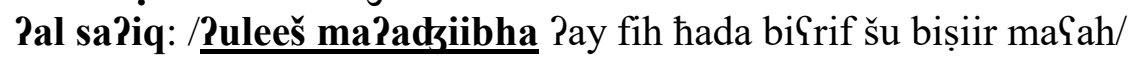

Pal šurți: /țayeb hay ruxașak ?u allah maৎak/

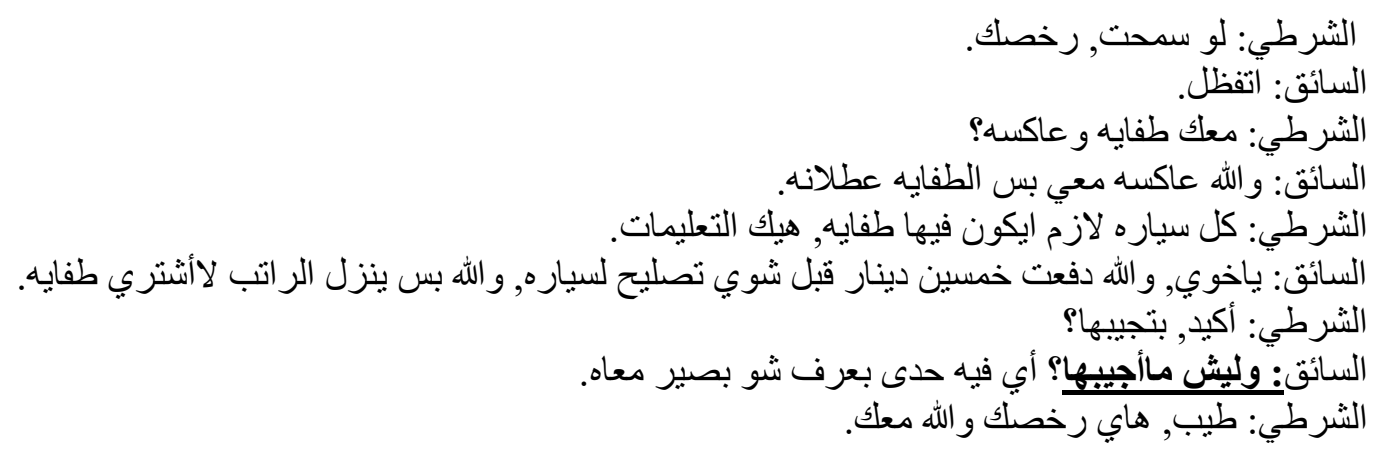

The police office: Your driving license, please. 
The driver: Here it is.

The police officer: Do you have a fire extinguisher and reflecting triangle.

The driver: I do have a reflecting triangle, but the fire extinguisher is broken down.

The police officer: The regulations dictate that every car should contain a fire extinguisher and reflecting triangle.

The driver: Oh, brother. I swear that I have paid 50 JD to repair my car. I pledge that I will buy a fire extinguisher as soon as I receive my salary.

The police officer: Are you sure you will have it?

The driver: Why do not I have such a thing? Who knows what a shortage of fire extinguisher might cause.

The police officer: Ok, here is your driving license, Allah's peace be with you.

\section{Dialogue No (4): Informal WH- Question}

hatim: /șabeh Galeena yazalameh maSana mașari/

Pabd Pallah: /yaxooy il؟atab Galnađar wallah mani šayfak/

hatim: /badna inyalbak maSana ilyoom/

Pabd Pallah: /layalabah walla itxaliniiš Paguulha/

hatim: /badi PatlaS Salmantiga ilhurah Padawer Gala siyaarah wubti@rif maSlumati bilsiyaraat zay maSlumaat raћmet dzediti bilkambyutar yaSni badi itrafigni ?u bilwagt ili bitkuun fih fađi/

Pabd Pallah: /yazalameh miin bigdar ?igullak la?/

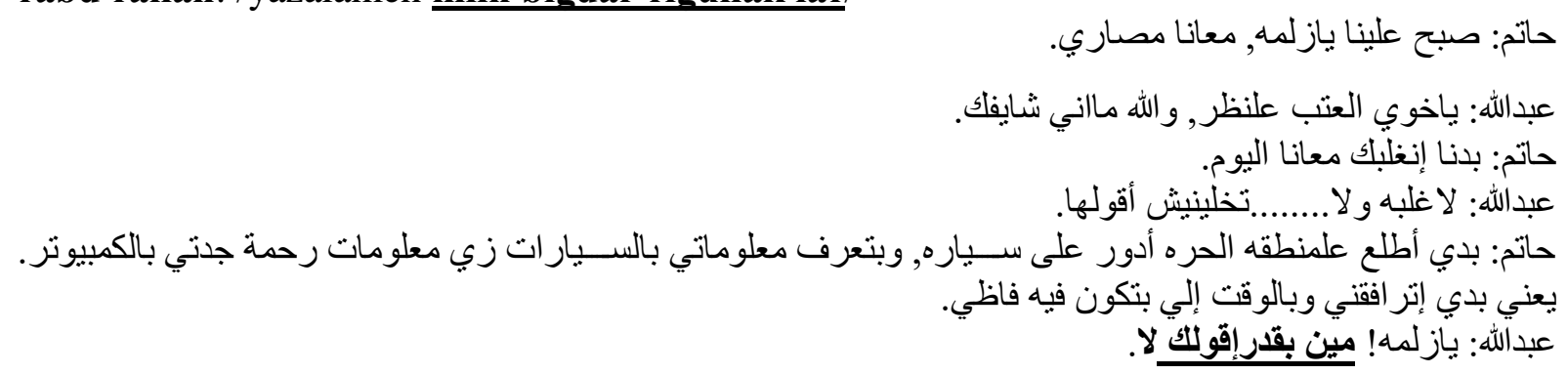

Hatem: Say good morning, man. It seems that you are trying to ignore me.

Abdullah: Oh brother, I was really unable to recognize you, it sounds that I have a problem with my sight.

Hatem: I need you to do something for me today, but I am afraid that would impose a burden on you.

Abdullah: Do not mention it, man.

Hatem: I want to go to the free zone to buy a car, and I do not have sufficient knowledge to do that alone. So, I need you to go with me there, any time you specify.

Abdullah: Man! Who dares to say no to you? 